\title{
Implementasi Algoritma Cosine Similarity pada sistem arsip dokumen di Universitas Islam Sultan Agung
}

\author{
Dedy Kurniadi ${ }^{1}$, Sam Farisa Chaerul Haviana ${ }^{2}$, Andika Novianto ${ }^{3}$ \\ ${ }^{1}$ Universitas Islam Sultan Agung/Jurusan Teknik Informatika \\ JI.Raya Kaligawe KM.4, telp: 024-6583584, e-mail: ddy.kurniadi@unissula.ac.id \\ ${ }^{2}$ Universitas Islam Sultan Agung/Jurusan Teknik Informatika \\ JI.Raya Kaligawe KM.4, telp: 024-6583584, e-mail: sam@unissula.ac.id \\ ${ }^{3}$ Universitas Islam Sultan Agung/Jurusan Teknik Informatika \\ Jl.Raya Kaligawe KM.4, telp: 024-6583584, e-mail: andika@unissula.ac.id
}

\section{ARTICLE INFO}

Article history:

Received 20 September 2019

Received in revised form 19 December 2019

Accepted 02 January 2020

Available online 31 January 2020

\begin{abstract}
Archiving in University that have not been well organized will cause a problems, the documents need for structuring and archives properly in the systems for the good standard a universities. The most importance of ease in finding the required archives is an important reason why it is necessary to develop an archive search system that can facilitate and improve the process of searching the archived document. Apllying cosine similarity algorithm in Information Systems is a solution for University to organizing archived documents, results from this reserach is the systems can show the relavant document from database list with precision $88.8 \%$ and recall $76.1 \%$ from all the data in database.
\end{abstract}

Keywords: Cosine Similarity, Information Systems, precision, recall

\section{Introduction}

Arsip mulanya berasal dari bahasa yunani, bahasa yang digunakan sebagai penyebutan arsip adalah "Archivum" dari kata Archivum kemudian berkembang lagi menjadi lebih spesifik didalam bahasa belanda yang disebutkan dengan kata "Archief" yang berarti wadah atau tempat yang digunakan untuk menyimpan catatan-catatan atau gambar-gambar yang digunakan sebagai bahan untuk mengingat kembali [1].

Berkembangnya zaman metode penggunaan arsip mulai diterapkan pada media elektronik, penggunaan sistem elektronik bisa mempermudah dalam pengarsipan sebuah dokumen namun dengan banyaknya data yang ada perlu diperhatikan dokumen-dokumen yang relevan dengan yang dicari sehingga tidak menimbulkan data sampah dan menemukan dokumen yang berkualitas [2].

Pengelolaan yang dilakukan di Biro Administrasi Umum Universitas Islam Sultan Agung Semarang, masih diolah dengan secara konvensional, hal tersebut sangat berpotensi mengakibatkan berbagai macam masalah, dan masalah yang sering terjadi adalah seperti dokumen hilang, rusak dan terbengkalai. Dengan pengelolaan secara konvensional seperti ini juga akan menimbulkan pemborosan pada resource lembaga [12].

Sistem informasi kearsipan ini diterapkan di Biro Administrasi Umum UNISSULA yang mana pada fungsi pencariannya sistem informasi ini menggunakan Algoritma Cosine Similarity, 
salah satu algoritma yang bisa menangani dokumen sebagai solusi dari model pengelolaan arsip dengan banyak data secara terkomputerisasi agar pencarian datanya bisa relevan ketika diproses, sistem ini mencari arsip digital dengan menghitung bobot teks judul dokumen dan isi dokumen kemudian akan dibobotkan dan dicocoknya dengan data yang ada di database.

\section{Research Method}

Dalam memodelkan dokumen-dokumen berbentuk teks terdapat beberapa cara. Misalnya, data teks bisa dijadikan atau direpresentasikan dalam wadah data kata atau sebagai kantongkantong kata, di mana kata-kata yang dicari dan yang akan diasumsikan muncul secara independen dalam bentuk urutan yang tidak material. Model seperti ini yaitu model dengan menggunakan kantong kata banyak dimanfaatkan dan digunakan dalam pengambilan informasi dan teks mining [3] [4].

Dalam kearsipan, database pasti akan penuh dengan record data dokumen arsip dengan jumlah yang besar. Jumlah data tersebut akan menimbulkan data-data di dalam database tersebut memiliki kemiripan antar dokumen yang satu dengan yang lainnya. Hal tersebut bisa diselesaikan dengan menerapkan data mining, konsep data mining dalam pencarian dokumen menggunakan cosine similarity terdiri dari proses Stemming menghilangkan imbuhan, kemudian proses stopword mengidentifikasi kata dasar, dan kemudian dilakukan tokenisasi melakukan penghitungan kata dasar yang muncul di suatu dokumen, kemudian meghitung bobot kata dari tiap dokumen, dan kemudian langkah yang terakhir adalah menghitung vektor yang dihasilkan dari proses penghitungan dari tiap kata dan antar kata yang dicari data dokumen, apabila jumlah vektornya mendekati nilai cos 1 maka tingkat kemiripannya semakin tinggi [5] .

Metode algoritma cosine similarity sendiri adalah salah satu metode yang bisa dimanfaatkan sebagai metode pencarian data di dalam data mining dan sering digunakan untuk mendeteksi dokumen-dokumen yang mirip, cosine similarity akan menghitung tingkat kesamaan antar dua buah atau lebih dari objek yang dinyatakan dalam vektor jumlahnya ada dua vektor dengan menggunakan kata kunci (cosine) [6] [7]. Jadi cosine similarity dapat digunakan untuk menemukan kemiripan dokumen dalam data set dengan jumlah yang besar dan dapat lebih cepat dan sesuai menemukan dokumen yang dicari.

Fungsi Cosine Similarity dapat dinyatakan dengan rumus:

Dimana: $\mathrm{z}$

$$
\text { Similarity }(X, Y)=\frac{|X \cap Y|}{|X|^{\frac{1}{2}} \cdot|Y|^{\frac{1}{2}}}
$$

$|X \cap Y|$ adalah jumlah kata yang ada pada dokumen $\mathrm{X}$ dan dokumen $\mathrm{Y}$

$|X|$ adalah jumlah kata yang ada pada dokumen $X$

$|Y|$ adalah jumlah kata yang ada pada dokumen $Y$

Tahapan dalam melakukan implementasi Cosine Similarity, terdiri dari beberapa tahapan-tahapan yaitu, Stemming merupakan tahapan untuk menemukan kata dasar dari sebuah kata. Tahapan atau proses stemming merupakan proses menghilangkan imbuhan awalan, sisipan dan akhiran untuk mendapatkan kata dasar, setelah tahapan atau proses steming dilakukan, tahapan selanjutnya adalah menentukan indeksasi/ tokenisasi, proses tersebut melakukan penghitungan jumlah kata yang ada di dalam dokumen dan menghitung TF (Term Frequency), DF (Document Frequency), dan IDF (Invers Document Frequency) pada dokumen tersebut [8] [9] menggunakan rumus berikut :

$$
\text { idf }=\log (\mathrm{n} / \mathrm{df})
$$

TRANSFORMATIKA Vol. 17, No. 2, January 2020: $124-132$ 
dimana:

$$
\begin{array}{ll}
\mathrm{idf} & =\text { Invers Document Frequency } \\
\mathrm{n} & =\text { jumlah term/kata tiap dokumen (Term Frequency) } \\
\mathrm{df} & =\text { Document Frequency }
\end{array}
$$

Setelah melakukan indeksasi/tokenisasi, dan menemukan TF (Term Frequency), DF (Document Frequency), dan IDF (Invers Document Frequency) pada setiap term, maka selanjutnya dilakukan perhitungan bobot WDT (Weight Document Term) dari setiap term [10] yang ada dengan menggunakan rumus:

$$
\text { (wdt) BOBOT [i] = tf[i] } \mathrm{x} \text { idf[i] }
$$

dimana:

$$
\begin{aligned}
& \text { tf[i] : Term pada index } \mathrm{i} \\
& \mathrm{idf}[\mathrm{i}]: \text { IDF pada index } \mathrm{i}
\end{aligned}
$$

Setelah selesai melakukan perhitungan WDT (Weight Document Term), maka selanjutnya melakukan perhitungan perkalian vektor antara Vektor Q dan Vektor D pada tiap term [11]. Vektor Q adalah hasil perhitungan wdt pada kata kunci dan Vektor D merupakan hasil perhitungan wdt pada tiap dokumen, Perkalian Vektor Q dan Vektor D dapat dinyatakan dengan rumus:

$$
Q . D[i]=\sum_{j=1}^{n} w d t\left(Q_{j}\right) \times w d t\left(D[i]_{j}\right)
$$

dimana :

wdt(Q): Bobot Q pada kata ke $\mathrm{j}$

$\mathrm{D}[\mathrm{i}] \mathrm{j} \quad$ : Bobot D ke I pada Kata ke j

Apabila hasil perkalian Vektor Q dan Vektor D telah ditemukan, maka langkah selanjutnya yang dilakukan adalah menghitung panjang Vektor tiap term per dokumen yaitu dengan rumus:

$$
|Q|=\sqrt{\sum_{j=1}^{n} w d t(Q)^{2}}
$$

Setelah ditemukan hasil panjang vektor maka langkah terakhir yaitu menemukan hasil dari perhitungan Cosine Similarity yaitu menggunakan rumus :

dimana:

$$
\text { similarity }=\cos =\frac{Q \cdot D_{i}}{|Q|\left|D_{i}\right|}
$$

Q.D $\quad$ : Hasil perkalian vektor

$|\mathrm{Q}|\left|\mathrm{D}_{\mathrm{i}}\right|$ : Hasil panjang vektor

\section{Results and Analysis}

Penggunaan Algoritma Cosine Similarity yang menentukan hasil terbaik dalam suatu pencarian, melalui beberapa proses, tahapan pertama melakukan stemming dari data yang ada pada database proses stemming menemukan kata dasar dengan menggunakan stopword. Stopword merupakan kata umum yang biasanya muncul dalam jumlah besar dan dianggap tidak memiki makna, seperti "yang”, "di”, "ke: dan lain lain. Proses stemming diawali dengan melakukan proses

Implementasi Algoritma Cosine Similarity pada sistem arsip dokumen di Universitas Islam Sultan

Agung (Dedy Kurniadi) 
menghilangkan imbuhan, awalan dan akhiran dari proses tersebut kemudian ditemukan kata dasar dari suatu kata di dalam dokumen yang di masukkan dalam kata kunci pencarian ataupun kata kunci dari judul dokumen. Berikut merupakan sampel data dalam melakukan proses stemming ditunjukkan pada tabel 3.1.

Tabel 3.1 Data set Arsip pada database.

\begin{tabular}{|c|c|c|}
\hline & Judul & Isi \\
\hline $\mathrm{Q}$ & Pemberhentian & \\
\hline D1 & $\begin{array}{l}\text { PEMBERHENTIAN DAN } \\
\text { PENGANGKATAN ANGGOTA } \\
\text { SENAT UNISSULA 2014-2018 }\end{array}$ & $\begin{array}{l}\text { SK dengan Dasar Pengunduran Diri Prof. Choliq } \\
\text { Dahlan dan Dr. Ibnu Khajar serta penambahan Prof. } \\
\text { Widodo }\end{array}$ \\
\hline D2 & $\begin{array}{l}\text { PEMBERHENTIAN DAN } \\
\text { PENGANGKATAN KETUA } \\
\text { PROGRAM MAGISTER TEKNIK } \\
\text { ELEKTRO }\end{array}$ & $\begin{array}{l}\text { Mengangkat Saudara Much Imam Ibnu Subroto } \\
\text { sebagai Kaprodi MTE }\end{array}$ \\
\hline D3 & $\begin{array}{l}\text { PEMBERHENTIAN KEPALA UPT } \\
\text { SISTEM PENGENDALIAN MUTU } \\
\text { INTERNAL (SPMI) }\end{array}$ & $\begin{array}{l}\text { SK rektor ini memberhentikan dengan hormat } \\
\text { Saudara Ahmad Salim, SE sebagai Kepala UPT } \\
\text { SPMI terhitung mulai tanggal } 31 \text { Mei } 2014\end{array}$ \\
\hline D4 & $\begin{array}{l}\text { Pemberhentian dengan hormat karena } \\
\text { mencapai batas usia purna tugas an sdr } \\
\text { Achmad Farouq }\end{array}$ & $\begin{array}{l}\text { Surat YBWSA ini menerangkan Pemberhentian } \\
\text { dengan hormat karena mencapai batas usia purna } \\
\text { tugas an sdr Achmad Farouq terhitung mulai tanggal } \\
1 \text { Mei } 2014\end{array}$ \\
\hline D5 & $\begin{array}{l}\text { Pemberhentian dengan hormat karena } \\
\text { mencapai batas usia purna tugas sebagai } \\
\text { Tenaga Pengajar Tetap Fakultas } \\
\text { Kedokteran UNISSULA }\end{array}$ & $\begin{array}{l}\text { SK YBWSA ini menerangkan Pemberhentian dengan } \\
\text { hormat karena mencapai batas usia purna tugas } \\
\text { sebagai Tenaga Pengajar Tetap Fakultas Kedokteran } \\
\text { UNISSULA an dr. Hj. Utari terhitung mulai tanggal } 1 \\
\text { Mei } 2014\end{array}$ \\
\hline D6 & $\begin{array}{l}\text { Pemberhentian dengan hormat karena } \\
\text { mencapai batas usia purna tugas sebagai } \\
\text { Tenaga Pengajar Tetap Fakultas } \\
\text { Kedokteran UNISSULA }\end{array}$ & $\begin{array}{l}\text { SK YBWSA ini menerangkan Pemberhentian dengan } \\
\text { hormat karena mencapai batas usia purna tugas } \\
\text { sebagai Tenaga Pengajar Tetap Fakultas Kedokteran } \\
\text { UNISSULA an dr. H. Muktasim Billah, Sp.S } \\
\text { terhitung mulai tanggal } 1 \text { Februari } 2014\end{array}$ \\
\hline
\end{tabular}

Setelah melakukan stemming selanjutnya dilakukan Praprosessing terhadap judul dan isi

1. Judul dan isi digabungkan

2. Hapus Tanda Baca

3. Hapus Kata Bantu, Kata Ganti Orang, dll (Stopword)

4. Hapus imbuhan pada Kalimat (Stemming)

Setelah dilakukan proses stemming dan praprosessing maka ditemukan hasil Praprosessing dapat dilihat pada Tabel 4.2.

Tabel 2.2 hasil dari praprosessing.

\begin{tabular}{|l|l|}
\hline Term & \multicolumn{1}{|c|}{ Data hasil praprosessing } \\
\hline Q & Henti \\
\hline D1 & $\begin{array}{l}\text { henti hormat capai batas usia purna tugas sdr achmad farouq surat ybwsa erang henti hormat capai batas } \\
\text { usia purna tugas sdr achmad farouq hitung tanggal mei }\end{array}$ \\
\hline D2 & \begin{tabular}{l} 
henti kangkat anggota senat unissula sk dasar undur prof choliq dahl dr ibnu khajar tambah prof widodo \\
\hline D3
\end{tabular} \\
$\begin{array}{l}\text { henti kangkat ketua program magister teknik elektro angkat saudara much imam ibnu subroto kaprod } \\
\text { me }\end{array}$ \\
\hline D4 & $\begin{array}{l}\text { henti kepala upt sistem kendali mutu internal spm sk rektor henti hormat saudara ahmad salim kepala } \\
\text { upt spm hitung tanggal mei }\end{array}$ \\
\hline
\end{tabular}

TRANSFORMATIKA Vol. 17, No. 2, January 2020 : $124-132$ 


\begin{tabular}{|l|l|}
\hline D5 & $\begin{array}{l}\text { henti hormat capai batas usia purna tugas tenaga kajar fakultas dokter unissula sk ybwsa erang henti } \\
\text { hormat capai batas usia purna tugas tenaga kajar fakultas dokter unissula dr hj utar hitung tanggal mei }\end{array}$ \\
\hline D6 & $\begin{array}{l}\text { henti hormat capai batas usia purna tugas tenaga kajar fakultas dokter unissula sk ybwsa erang henti } \\
\text { hormat capai batas usia purna tugas tenaga kajar fakultas dokter unissula dr h muktasim bil sps hitung } \\
\text { tanggal februari }\end{array}$ \\
\hline
\end{tabular}

Selanjutnya, proses yang dilakukan yaitu Indeksasi/Tokenisasi dan Hitung TF (Term Frequency), DF (Document Frequency), dan IDF (Invers Document Frequency)

1.Pisahkan tiap kata

2.Kata yang sama dianggap menjadi 1 kata

3.TF : Hitung jumlah kata yang muncul pada Dokumen

4.DF : Jumlah Seluruh TF

5.IDF : Invert DF

Tabel 3.3 Hasil tokenisasi

\begin{tabular}{|c|c|c|c|c|c|c|c|c|c|}
\hline Kata Kunci & Q & D1 & D2 & D3 & D4 & D5 & D6 & df & $\begin{array}{c}\text { idf }= \\
\log (n / d f)\end{array}$ \\
\hline achmad & 0 & 2 & 0 & 0 & 0 & 0 & 0 & 2 & 0,54406804 \\
\hline ahmad & 0 & 0 & 0 & 0 & 1 & 0 & 0 & 1 & 0,84509804 \\
\hline anggota & 0 & 0 & 1 & 0 & 0 & 0 & 0 & 1 & 0,84509804 \\
\hline angkat & 0 & 0 & 0 & 1 & 0 & 0 & 0 & 1 & 0,84509804 \\
\hline batas & 0 & 2 & 0 & 0 & 0 & 2 & 2 & 6 & 0,06694679 \\
\hline bil & 0 & 0 & 0 & 0 & 0 & 0 & 1 & 1 & 0,84509804 \\
\hline capai & 0 & 2 & 0 & 0 & 0 & 2 & 2 & 6 & 0,06694679 \\
\hline choliq & 0 & 0 & 1 & 0 & 0 & 0 & 0 & 1 & 0,84509804 \\
\hline dahl & 0 & 0 & 1 & 0 & 0 & 0 & 0 & 1 & 0,84509804 \\
\hline dasar & 0 & 0 & 1 & 0 & 0 & 0 & 0 & 1 & 0,84509804 \\
\hline dokter & 0 & 0 & 0 & 0 & 0 & 2 & 2 & 4 & 0,24303805 \\
\hline $\mathrm{dr}$ & 0 & 0 & 1 & 0 & 0 & 1 & 1 & 3 & 0,36797679 \\
\hline elektro & 0 & 0 & 0 & 1 & 0 & 0 & 0 & 1 & 0,84509804 \\
\hline erang & 0 & 1 & 0 & 0 & 0 & 1 & 1 & 3 & 0,36797679 \\
\hline fakultas & 0 & 0 & 0 & 0 & 0 & 2 & 2 & 4 & 0,24303805 \\
\hline farouq & 0 & 2 & 0 & 0 & 0 & 0 & 0 & 2 & 0,54406804 \\
\hline februari & 0 & 0 & 0 & 0 & 0 & 0 & 1 & 1 & 0,84509804 \\
\hline $\mathrm{h}$ & 0 & 0 & 0 & 0 & 0 & 0 & 1 & 1 & 0,84509804 \\
\hline henti & 1 & 2 & 1 & 1 & 2 & 2 & 2 & 11 & $-0,19629465$ \\
\hline hitung & 0 & 1 & 0 & 0 & 1 & 1 & 1 & 4 & 0,24303805 \\
\hline hj & 0 & 0 & 0 & 0 & 0 & 1 & 0 & 1 & 0,84509804 \\
\hline hormat & 0 & 2 & 0 & 0 & 1 & 2 & 2 & 7 & 0 \\
\hline ibnu & 0 & 0 & 1 & 1 & 0 & 0 & 0 & 2 & 0,54406804 \\
\hline imam & 0 & 0 & 0 & 1 & 0 & 0 & 0 & 1 & 0,84509804 \\
\hline internal & 0 & 0 & 0 & 0 & 1 & 0 & 0 & 1 & 0,84509804 \\
\hline
\end{tabular}

Implementasi Algoritma Cosine Similarity pada sistem arsip dokumen di Universitas Islam Sultan 


\begin{tabular}{|c|c|c|c|c|c|c|c|c|c|}
\hline Kata Kunci & Q & D1 & D2 & D3 & D4 & D5 & D6 & df & $\begin{array}{c}\mathrm{idf}= \\
\log (\mathrm{n} / \mathrm{df})\end{array}$ \\
\hline kajar & 0 & 0 & 0 & 0 & 0 & 2 & 2 & 4 & 0,24303805 \\
\hline kangkat & 0 & 0 & 1 & 1 & 0 & 0 & 0 & 2 & 0,54406804 \\
\hline kaprod & 0 & 0 & 0 & 1 & 0 & 0 & 0 & 1 & 0,84509804 \\
\hline kendali & 0 & 0 & 0 & 0 & 1 & 0 & 0 & 1 & 0,84509804 \\
\hline kepala & 0 & 0 & 0 & 0 & 2 & 0 & 0 & 2 & 0,54406804 \\
\hline ketua & 0 & 0 & 0 & 1 & 0 & 0 & 0 & 1 & 0,84509804 \\
\hline khajar & 0 & 0 & 1 & 0 & 0 & 0 & 0 & 1 & 0,84509804 \\
\hline magister & 0 & 0 & 0 & 1 & 0 & 0 & 0 & 1 & 0,84509804 \\
\hline mei & 0 & 1 & 0 & 0 & 1 & 1 & 0 & 3 & 0,36797679 \\
\hline mte & 0 & 0 & 0 & 1 & 0 & 0 & 0 & 1 & 0,84509804 \\
\hline much & 0 & 0 & 0 & 1 & 0 & 0 & 0 & 1 & 0,84509804 \\
\hline muktasim & 0 & 0 & 0 & 0 & 0 & 0 & 1 & 1 & 0,84509804 \\
\hline mutu & 0 & 0 & 0 & 0 & 1 & 0 & 0 & 1 & 0,84509804 \\
\hline prof & 0 & 0 & 2 & 0 & 0 & 0 & 0 & 2 & 0,54406804 \\
\hline program & 0 & 0 & 0 & 1 & 0 & 0 & 0 & 1 & 0,84509804 \\
\hline purna & 0 & 2 & 0 & 0 & 0 & 2 & 2 & 6 & 0,06694679 \\
\hline rektor & 0 & 0 & 0 & 0 & 1 & 0 & 0 & 1 & 0,84509804 \\
\hline salim & 0 & 0 & 0 & 0 & 1 & 0 & 0 & 1 & 0,84509804 \\
\hline saudara & 0 & 0 & 0 & 1 & 1 & 0 & 0 & 2 & 0,54406804 \\
\hline sdr & 0 & 2 & 0 & 0 & 0 & 0 & 0 & 2 & 0,54406804 \\
\hline senat & 0 & 0 & 1 & 0 & 0 & 0 & 0 & 1 & 0,84509804 \\
\hline sistem & 0 & 0 & 0 & 0 & 1 & 0 & 0 & 1 & 0,84509804 \\
\hline sk & 0 & 0 & 1 & 0 & 1 & 1 & 1 & 4 & 0,24303805 \\
\hline spm & 0 & 0 & 0 & 0 & 2 & 0 & 0 & 2 & 0,54406804 \\
\hline sps & 0 & 0 & 0 & 0 & 0 & 0 & 1 & 1 & 0,84509804 \\
\hline subroto & 0 & 0 & 0 & 1 & 0 & 0 & 0 & 1 & 0,84509804 \\
\hline surat & 0 & 1 & 0 & 0 & 0 & 0 & 0 & 1 & 0,84509804 \\
\hline tambah & 0 & 0 & 1 & 0 & 0 & 0 & 0 & 1 & 0,84509804 \\
\hline tanggal & 0 & 1 & 0 & 0 & 1 & 1 & 1 & 4 & 0,24303805 \\
\hline teknik & 0 & 0 & 0 & 1 & 0 & 0 & 0 & 1 & 0,84509804 \\
\hline tenaga & 0 & 0 & 0 & 0 & 0 & 2 & 2 & 4 & 0,24303805 \\
\hline tugas & 0 & 2 & 0 & 0 & 0 & 2 & 2 & 6 & 0,06694679 \\
\hline undur & 0 & 0 & 1 & 0 & 0 & 0 & 0 & 1 & 0,84509804 \\
\hline unissula & 0 & 0 & 1 & 0 & 0 & 2 & 2 & 5 & 0,14612804 \\
\hline upt & 0 & 0 & 0 & 0 & 2 & 0 & 0 & 2 & 0,54406804 \\
\hline usia & 0 & 2 & 0 & 0 & 0 & 2 & 2 & 6 & 0,06694679 \\
\hline utar & 0 & 0 & 0 & 0 & 0 & 1 & 0 & 1 & 0,84509804 \\
\hline widodo & 0 & 0 & 1 & 0 & 0 & 0 & 0 & 1 & 0,84509804 \\
\hline ybwsa & 0 & 1 & 0 & 0 & 0 & 1 & 1 & 3 & 0,36797679 \\
\hline
\end{tabular}

TRANSFORMATIKA Vol. 17, No. 2, January 2020 : $124-132$ 
Setelah ditemukan nilai TF (Term Frequency), DF (Document Frequency), dan IDF (Invers Document Frequency) pada setiap term, maka selanjutnya dilakukan perhitungan bobot wdt (weight document term) dari setiap term yang ada.

Tabel 3.4 Tabel hasil perhitungan wdt (weight document term).

\begin{tabular}{|c|c|c|c|c|c|c|c|}
\hline Kata Kunci & Q & D1 & D2 & D3 & D4 & D5 & D6 \\
\hline achmad & 0 & 1,08813609 & 0 & 0 & 0 & 0 & 0 \\
\hline ahmad & 0 & 0 & 0 & 0 & 0,845098 & 0 & 0 \\
\hline anggota & 0 & 0 & 0,845098 & 0 & 0 & 0 & 0 \\
\hline angkat & 0 & 0 & 0 & 0,845098 & 0 & 0 & 0 \\
\hline batas & 0 & 0,13389358 & 0 & 0 & 0 & 0,133894 & 0,133894 \\
\hline bil & 0 & 0 & 0 & 0 & 0 & 0 & 0,845098 \\
\hline capai & 0 & 0,13389358 & 0 & 0 & 0 & 0,133894 & 0,133894 \\
\hline choliq & 0 & 0 & 0,845098 & 0 & 0 & 0 & 0 \\
\hline dahl & 0 & 0 & 0,845098 & 0 & 0 & 0 & 0 \\
\hline dasar & 0 & 0 & 0,845098 & 0 & 0 & 0 & 0 \\
\hline dokter & 0 & 0 & 0 & 0 & 0 & 0,486076 & 0,486076 \\
\hline $\mathrm{dr}$ & 0 & 0 & 0,367977 & 0 & 0 & 0,367977 & 0,367977 \\
\hline elektro & 0 & 0 & 0 & 0,845098 & 0 & 0 & 0 \\
\hline erang & 0 & 0,36797679 & 0 & 0 & 0 & 0,367977 & 0,367977 \\
\hline fakultas & 0 & 0 & 0 & 0 & 0 & 0,486076 & 0,486076 \\
\hline farouq & 0 & 1,08813609 & 0 & 0 & 0 & 0 & 0 \\
\hline februari & 0 & 0 & 0 & 0 & 0 & 0 & 0,845098 \\
\hline $\mathrm{h}$ & 0 & 0 & 0 & 0 & 0 & 0 & 0,845098 \\
\hline henti & $-0,196294645$ & $-0,39258929$ & $-0,19629$ & $-0,19629$ & $-0,39259$ & $-0,39259$ & $-0,39259$ \\
\hline hitung & 0 & 0,24303805 & 0 & 0 & 0,243038 & 0,243038 & 0,243038 \\
\hline hj & 0 & 0 & 0 & 0 & 0 & 0,845098 & 0 \\
\hline hormat & 0 & 0 & 0 & 0 & 0 & 0 & 0 \\
\hline ibnu & 0 & 0 & 0,544068 & 0,544068 & 0 & 0 & 0 \\
\hline imam & 0 & 0 & 0 & 0,845098 & 0 & 0 & 0 \\
\hline internal & 0 & 0 & 0 & 0 & 0,845098 & 0 & 0 \\
\hline kajar & 0 & 0 & 0 & 0 & 0 & 0,486076 & 0,486076 \\
\hline kangkat & 0 & 0 & 0,544068 & 0,544068 & 0 & 0 & 0 \\
\hline kaprod & 0 & 0 & 0 & 0,845098 & 0 & 0 & 0 \\
\hline kendali & 0 & 0 & 0 & 0 & 0,845098 & 0 & 0 \\
\hline kepala & 0 & 0 & 0 & 0 & 1,088136 & 0 & 0 \\
\hline ketua & 0 & 0 & 0 & 0,845098 & 0 & 0 & 0 \\
\hline khajar & 0 & 0 & 0,845098 & 0 & 0 & 0 & 0 \\
\hline magister & 0 & 0 & 0 & 0,845098 & 0 & 0 & 0 \\
\hline mei & 0 & 0,36797679 & 0 & 0 & 0,367977 & 0,367977 & 0 \\
\hline
\end{tabular}


ISSN: $1693-3656$

\begin{tabular}{|c|c|c|c|c|c|c|c|}
\hline Kata Kunci & Q & D1 & D2 & D3 & D4 & D5 & D6 \\
\hline mte & 0 & 0 & 0 & 0,845098 & 0 & 0 & 0 \\
\hline much & 0 & 0 & 0 & 0,845098 & 0 & 0 & 0 \\
\hline muktasim & 0 & 0 & 0 & 0 & 0 & 0 & 0,845098 \\
\hline mutu & 0 & 0 & 0 & 0 & 0,845098 & 0 & 0 \\
\hline prof & 0 & 0 & 1,088136 & 0 & 0 & 0 & 0 \\
\hline program & 0 & 0 & 0 & 0,845098 & 0 & 0 & 0 \\
\hline purna & 0 & 0,13389358 & 0 & 0 & 0 & 0,133894 & 0,133894 \\
\hline rektor & 0 & 0 & 0 & 0 & 0,845098 & 0 & 0 \\
\hline salim & 0 & 0 & 0 & 0 & 0,845098 & 0 & 0 \\
\hline saudara & 0 & 0 & 0 & 0,544068 & 0,544068 & 0 & 0 \\
\hline $\mathrm{sdr}$ & 0 & 1,08813609 & 0 & 0 & 0 & 0 & 0 \\
\hline senat & 0 & 0 & 0,845098 & 0 & 0 & 0 & 0 \\
\hline sistem & 0 & 0 & 0 & 0 & 0,845098 & 0 & 0 \\
\hline sk & 0 & 0 & 0,243038 & 0 & 0,243038 & 0,243038 & 0,243038 \\
\hline spm & 0 & 0 & 0 & 0 & 1,088136 & 0 & 0 \\
\hline sps & 0 & 0 & 0 & 0 & 0 & 0 & 0,845098 \\
\hline subroto & 0 & 0 & 0 & 0,845098 & 0 & 0 & 0 \\
\hline surat & 0 & 0,84509804 & 0 & 0 & 0 & 0 & 0 \\
\hline tambah & 0 & 0 & 0,845098 & 0 & 0 & 0 & 0 \\
\hline tanggal & 0 & 0,24303805 & 0 & 0 & 0,243038 & 0,243038 & 0,243038 \\
\hline teknik & 0 & 0 & 0 & 0,845098 & 0 & 0 & 0 \\
\hline tenaga & 0 & 0 & 0 & 0 & 0 & 0,486076 & 0,486076 \\
\hline tugas & 0 & 0,13389358 & 0 & 0 & 0 & 0,133894 & 0,133894 \\
\hline undur & 0 & 0 & 0,845098 & 0 & 0 & 0 & 0 \\
\hline unissula & 0 & 0 & 0,146128 & 0 & 0 & 0,292256 & 0,292256 \\
\hline upt & 0 & 0 & 0 & 0 & 1,088136 & 0 & 0 \\
\hline usia & 0 & 0,13389358 & 0 & 0 & 0 & 0,133894 & 0,133894 \\
\hline utar & 0 & 0 & 0 & 0 & 0 & 0,845098 & 0 \\
\hline widodo & 0 & 0 & 0,845098 & 0 & 0 & 0 & 0 \\
\hline ybwsa & 0 & 0,36797679 & 0 & 0 & 0 & 0,367977 & 0,367977 \\
\hline
\end{tabular}

Setelah dilakukan perhitungan wdt (weight document term) dengan hasil masing masing term dokumen memiliki bobot tersendiri, selanjutnya perlu dilakukan perhitungan perkalian vektor antara Vektor Q dan Vektor D pada tiap term.

Tabel 3.5 Perkalian vektor Q dan D

\begin{tabular}{|c|c|c|c|c|c|c|c|}
\hline Kata Kunci & $\mathrm{Q}$ & D1 & D2 & D3 & D4 & D5 & D6 \\
\hline achmad & 0 & 0 & 0 & 0 & 0 & 0 & 0 \\
\hline ahmad & 0 & 0 & 0 & 0 & 0 & 0 & 0 \\
\hline anggota & 0 & 0 & 0 & 0 & 0 & 0 & 0 \\
\hline angkat & 0 & 0 & 0 & 0 & 0 & 0 & 0 \\
\hline batas & 0 & 0 & 0 & 0 & 0 & 0 & 0 \\
\hline
\end{tabular}

TRANSFORMATIKA Vol. 17, No. 2, January 2020: 124-132 


\begin{tabular}{|c|c|c|c|c|c|c|c|}
\hline Kata Kunci & Q & D1 & $\mathrm{D} 2$ & D3 & $\mathrm{D} 4$ & D5 & D6 \\
\hline bil & 0 & 0 & 0 & 0 & 0 & 0 & 0 \\
\hline capai & 0 & 0 & 0 & 0 & 0 & 0 & 0 \\
\hline choliq & 0 & 0 & 0 & 0 & 0 & 0 & 0 \\
\hline dahl & 0 & 0 & 0 & 0 & 0 & 0 & 0 \\
\hline dasar & 0 & 0 & 0 & 0 & 0 & 0 & 0 \\
\hline dokter & 0 & 0 & 0 & 0 & 0 & 0 & 0 \\
\hline $\mathrm{dr}$ & 0 & 0 & 0 & 0 & 0 & 0 & 0 \\
\hline elektro & 0 & 0 & 0 & 0 & 0 & 0 & 0 \\
\hline erang & 0 & 0 & 0 & 0 & 0 & 0 & 0 \\
\hline fakultas & 0 & 0 & 0 & 0 & 0 & 0 & 0 \\
\hline farouq & 0 & 0 & 0 & 0 & 0 & 0 & 0 \\
\hline februari & 0 & 0 & 0 & 0 & 0 & 0 & 0 \\
\hline $\mathrm{h}$ & 0 & 0 & 0 & 0 & 0 & 0 & 0 \\
\hline henti & 0,038531588 & 0,07706318 & 0,038532 & 0,038532 & 0,077063 & 0,077063 & 0,077063 \\
\hline hitung & 0 & 0 & 0 & 0 & 0 & 0 & 0 \\
\hline hj & 0 & 0 & 0 & 0 & 0 & 0 & 0 \\
\hline hormat & 0 & 0 & 0 & 0 & 0 & 0 & 0 \\
\hline ibnu & 0 & 0 & 0 & 0 & 0 & 0 & 0 \\
\hline imam & 0 & 0 & 0 & 0 & 0 & 0 & 0 \\
\hline internal & 0 & 0 & 0 & 0 & 0 & 0 & 0 \\
\hline kajar & 0 & 0 & 0 & 0 & 0 & 0 & 0 \\
\hline kangkat & 0 & 0 & 0 & 0 & 0 & 0 & 0 \\
\hline kaprod & 0 & 0 & 0 & 0 & 0 & 0 & 0 \\
\hline kendali & 0 & 0 & 0 & 0 & 0 & 0 & 0 \\
\hline kepala & 0 & 0 & 0 & 0 & 0 & 0 & 0 \\
\hline ketua & 0 & 0 & 0 & 0 & 0 & 0 & 0 \\
\hline khajar & 0 & 0 & 0 & 0 & 0 & 0 & 0 \\
\hline magister & 0 & 0 & 0 & 0 & 0 & 0 & 0 \\
\hline mei & 0 & 0 & 0 & 0 & 0 & 0 & 0 \\
\hline mte & 0 & 0 & 0 & 0 & 0 & 0 & 0 \\
\hline much & 0 & 0 & 0 & 0 & 0 & 0 & 0 \\
\hline muktasim & 0 & 0 & 0 & 0 & 0 & 0 & 0 \\
\hline mutu & 0 & 0 & 0 & 0 & 0 & 0 & 0 \\
\hline prof & 0 & 0 & 0 & 0 & 0 & 0 & 0 \\
\hline program & 0 & 0 & 0 & 0 & 0 & 0 & 0 \\
\hline purna & 0 & 0 & 0 & 0 & 0 & 0 & 0 \\
\hline rektor & 0 & 0 & 0 & 0 & 0 & 0 & 0 \\
\hline salim & 0 & 0 & 0 & 0 & 0 & 0 & 0 \\
\hline saudara & 0 & 0 & 0 & 0 & 0 & 0 & 0 \\
\hline
\end{tabular}


ISSN: $1693-3656$

\begin{tabular}{|c|c|c|c|c|c|c|c|}
\hline Kata Kunci & Q & D1 & D2 & D3 & D4 & D5 & D6 \\
\hline sdr & 0 & 0 & 0 & 0 & 0 & 0 & 0 \\
\hline senat & 0 & 0 & 0 & 0 & 0 & 0 & 0 \\
\hline sistem & 0 & 0 & 0 & 0 & 0 & 0 & 0 \\
\hline sk & 0 & 0 & 0 & 0 & 0 & 0 & 0 \\
\hline spm & 0 & 0 & 0 & 0 & 0 & 0 & 0 \\
\hline sps & 0 & 0 & 0 & 0 & 0 & 0 & 0 \\
\hline subroto & 0 & 0 & 0 & 0 & 0 & 0 & 0 \\
\hline surat & 0 & 0 & 0 & 0 & 0 & 0 & 0 \\
\hline tambah & 0 & 0 & 0 & 0 & 0 & 0 & 0 \\
\hline tanggal & 0 & 0 & 0 & 0 & 0 & 0 & 0 \\
\hline teknik & 0 & 0 & 0 & 0 & 0 & 0 & 0 \\
\hline tenaga & 0 & 0 & 0 & 0 & 0 & 0 & 0 \\
\hline tugas & 0 & 0 & 0 & 0 & 0 & 0 & 0 \\
\hline undur & 0 & 0 & 0 & 0 & 0 & 0 & 0 \\
\hline unissula & 0 & 0 & 0 & 0 & 0 & 0 & 0 \\
\hline upt & 0 & 0 & 0 & 0 & 0 & 0 & 0 \\
\hline usia & 0 & 0 & 0 & 0 & 0 & 0 & 0 \\
\hline utar & 0 & 0 & 0 & 0 & 0 & 0 & 0 \\
\hline widodo & 0 & 0 & 0 & 0 & 0 & 0 & 0 \\
\hline ybwsa & 0 & 0 & 0 & 0 & 0 & 0 & 0 \\
\hline Total D0.Di & 0,038531588 & 0,07706318 & 0,038532 & 0,038532 & 0,077063 & 0,077063 & 0,077063 \\
\hline
\end{tabular}

setelah itu ditentukan tingkat kemiripan dokumen yang ditunjukkan pada tabel 3.6.

Tabel 3.6 Hasil perhitungan cosine similarity.

\begin{tabular}{|l|r|r|r|r|r|r|r|}
\hline Proses & \multicolumn{1}{|c|}{ Q } & \multicolumn{1}{c|}{ D1 } & \multicolumn{1}{c|}{ D2 } & \multicolumn{1}{c|}{ D3 } & \multicolumn{1}{c|}{ D4 } & \multicolumn{1}{c|}{ D5 } & \multicolumn{1}{c|}{ D6 } \\
\hline Q.D & 0,038531588 & 0,07706318 & 0,038532 & 0,038532 & 0,077063 & 0,077063 & 0,077063 \\
\hline$|\mathrm{V}|$ & 0,196294645 & 2,2437537 & 2,908287 & 2,963555 & 3,051918 & 1,849721 & 2,329943 \\
\hline$|\mathrm{Q}| .|\mathrm{V}|$ & & 0,44043684 & 0,570881 & 0,58173 & 0,599075 & 0,36309 & 0,457355 \\
\hline Similarity & & 0,175 & 0,067 & 0,066 & 0,129 & 0,212 & 0,168 \\
\hline
\end{tabular}

Kata kunci dari data masukan dicocokkan ke dalam dokumen yang ada dalam database. Contoh pencarian didalam sistem yang sudah diterapkan metode cosine similarity dengan menggunakan kata kunci "pemberhentian", akan muncul daftar dokumen dengan urutan dari tingkat similarity tertinggi hingga terendah ditunjukkan pada gambar 3.1.

TRANSFORMATIKA Vol. 17, No. 2, January 2020 : 124-132 


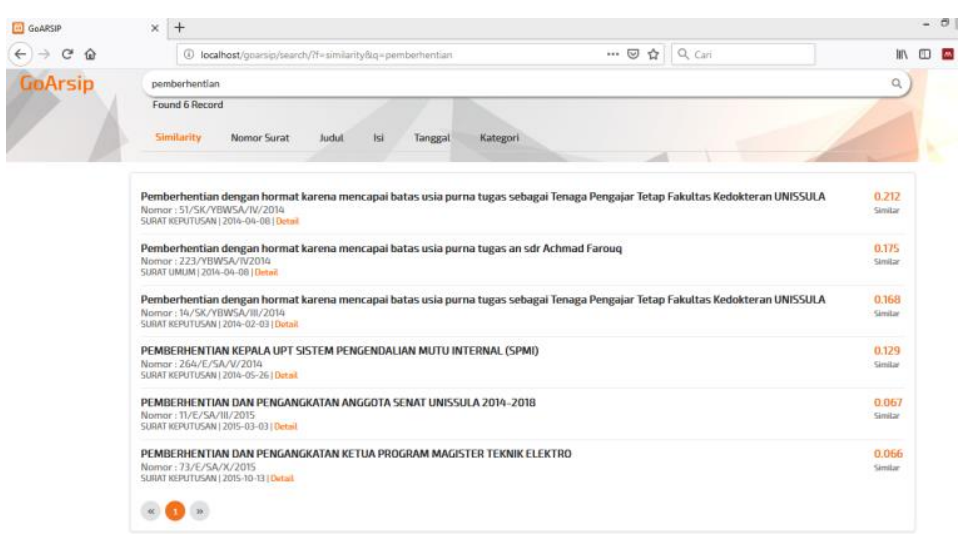

Gambar 3.1 Hasil pencarian di sistem

Dalam implementasi algoritma cosine similarity tingkat keberhasilan diukur dari seberapa besar kinerja algoritma tersebut bisa memecahkan masalah yang ada, metode cosine similarity diuji dengan menggunakan pengukuran precision (presisi) dan pengukuran recall. Perhitungan precision dan recall ditunjukkan pada tabel 3.7.

Tabel 3.7. Tabel Hasil Pengujian precision dan recall

\begin{tabular}{|l|c|c|c|}
\hline & Dokumen Relevan & Dokumen Tidak Relevan & Total \\
\hline Dokumen yang & $\mathbf{a}$ (hits) & $\mathbf{b}$ (noise) & $\mathbf{a + b}$ \\
ditemukan & 16 & 2 & $\mathbf{1 8}$ \\
\hline Dokumen yang tidak & $\mathbf{c}$ (misses) & $\mathbf{d}$ (reject) & $\mathbf{c + d}$ \\
ditemukan & 5 & 0 & $\mathbf{3}$ \\
\hline Total & $\mathbf{a + c}$ & $\mathbf{b + d}$ & $\mathbf{a + b + c + d}$ \\
& $\mathbf{2 1}$ & $\mathbf{0}$ & $\mathbf{2 1}$ \\
\hline
\end{tabular}

Keterangan:

a (hits) : Dokumen yang relevan

$\mathrm{b}$ (noise) : Dokumen yang tidak relevan

c (misses) : Dokumen relevan yang tidak ditemukan

$\mathrm{d}($ reject $) \quad$ : Dokumen tidak relevan yang tidak ditemukan

maka untuk menghitung precision dengan hasil sesuai Tabel 6 sebagai berikut:

$$
\begin{gathered}
\text { precision }=\frac{\text { Jumlah dokumen relevan yang terpang gil }(a)}{\text { Jumlah dokumen terpang gil dalam pencarian }(a+b)} \times 100 \\
\text { precision }=\frac{16}{18} \times 100=88.8 \%
\end{gathered}
$$

dan untuk menghitung recall dengan hasil sesuai Tabel 6 sebagai berikut:

$$
\begin{gathered}
\text { Recall }=\frac{\text { Jumlah dokumen relevan yang terpanggil }(a)}{\text { Jumlah dokumen relevan yang ada di database }(a+c)} \times 100 \\
\text { Recall }=\frac{16}{21} \times 100=76.1 \%
\end{gathered}
$$

Implementasi Algoritma Cosine Similarity pada sistem arsip dokumen di Universitas Islam Sultan 


\section{Conclusion}

Algoritma Cosine Similarity berhasil melakukan pencarian dokumen yang mirip atau yang relevan dengan memasukkan kata kunci dalam pencarian dokumen. Algoritma Cosine Similarity mampu menemukan dokumen dengan tingkat kemiripan yang tinggi sehingga dapat menemukan dokumen yang relevan, hal ini ditunjukkan dengan pengukuran kinerja Algoritma Cosine Similarity menunjukkan angka precision $88.8 \%$ dan recall $76.1 \%$.

\section{References}

[1] R. A. Pascapraharastyan, A. Supriyanto, and P. Sudarmaningtyas, "Rancang Bangun Sistem Informasi Manajemen Arsip Rumah Sakit Bedah Surabaya Berbasis Web," Sist. Inf., vol. 3, no. 1, pp. 72-77, 2014.

[2] M. Rifauddin, "Pengelolaan Arsip Elektronik Berbasis Teknologi," Khizanah Al- Hikmah J. Ilmu Perpustakaan, Informasi, dan Kearsipan, vol. 4, no. 2, pp. 168-178, 2016.

[3] O. Nurdiana, J. Jumadi, and D. Nursantika, "Perbandingan Metode Cosine Similarity Dengan Metode Jaccard Similarity Pada Aplikasi Pencarian Terjemah Al-Qur'an Dalam Bahasa Indonesia," J. Online Inform., vol. 1, no. 1, p. 59, 2016.

[4] S. Shum, N. Dehak, R. Dehak, and J. R. Glass, "Unsupervised Speaker Adaptation based on the Cosine Similarity for Text-Independent Speaker Verification," Proc. Odyssey, 2010.

[5] V. Thada and V. Jaglan, "Comparison of jaccard, dice, cosine similarity coefficient to find best fitness value for web retrieved documents using genetic algorithm," Int. J. Innov. Eng. Technol., vol. 2, no. 4, pp. 202-205, 2013.

[6] R. Mihalcea, C. Corley, and C. Strapparava, "Corpus-based and knowledge-based measures of text semantic similarity," Proc. Natl. Conf. Artif. Intell., vol. 1, pp. 775-780, 2006.

[7] M. E. Scholar, N. Engineering, T. Nadu, and T. Nadu, "a S Urvey on S Imilarity M Easures in T Ext M Ining," vol. 3, no. 1, pp. 19-28, 2016.

[8] J. Ramos, "Using TF-IDF to Determine Word Relevance in Document Queries," New Educ. Rev., vol. 42, no. 4, pp. 40-51, 2003.

[9] B. Li and L. Han, "Distance weighted cosine similarity measure for text classification," Lect. Notes Comput. Sci. (including Subser. Lect. Notes Artif. Intell. Lect. Notes Bioinformatics), vol. 8206 LNCS, pp. 611-618, 2013.

[10] B. Trstenjak, S. Mikac, and D. Donko, "KNN with TF-IDF based framework for text categorization," Procedia Eng., vol. 69, pp. 1356-1364, 2014.

[11] G. Sidorov, A. Gelbukh, H. Gómez-Adorno, and D. Pinto, "Soft similarity and soft cosine measure: Similarity of features in vector space model," Comput. y Sist., vol. 18, no. 3, pp. 491-504, 2014.

[12] Novianto, A., 2019 "Sistem Informasi Kearsipan Menggunakan Algoritma Cosine Similarity" Pada Biro Administrasi Umum Universitas Islam Sultan Agung, Semarang

TRANSFORMATIKA Vol. 17, No. 2, January 2020:124-132 